\title{
Article \\ CD74 and HLA-DRA in Cervical Carcinogenesis: Potential Targets for Antitumour Therapy
}

\author{
Carol K. Balakrishnan ${ }^{1}\left(\mathbb{D}\right.$, Gee Jun Tye ${ }^{1}\left(\mathbb{D}\right.$, Shandra Devi Balasubramaniam ${ }^{1,2}$ and Gurjeet Kaur ${ }^{1, *(\mathbb{C})}$ \\ 1 Institute for Research in Molecular Medicine, Universiti Sains Malaysia, \\ Minden 11800, Pulau Pinang, Malaysia; josephcarol144@gmail.com (C.K.B.); geejun@usm.my (G.J.T.); \\ shandrabala@gmail.com (S.D.B.) \\ 2 Unit of Microbiology, Faculty of Medicine, AIMST University, Bedong 08100, Semeling, Malaysia \\ * Correspondence: gurjeet@usm.my; Tel.: +604-6534865
}

check for updates

Citation: Balakrishnan, C.K.; Tye, G.J.; Balasubramaniam, S.D.; Kaur, G. CD74 and HLA-DRA in Cervical Carcinogenesis: Potential Targets for Antitumour Therapy. Medicina 2022, 58, 190. https://doi.org/10.3390/ medicina58020190

Academic Editor: Udo Jeschke

Received: 27 December 2021

Accepted: 24 January 2022

Published: 26 January 2022

Publisher's Note: MDPI stays neutral with regard to jurisdictional claims in published maps and institutional affiliations.

Copyright: (C) 2022 by the authors. Licensee MDPI, Basel, Switzerland. This article is an open access article distributed under the terms and conditions of the Creative Commons Attribution (CC BY) license (https:// creativecommons.org/licenses/by/ $4.0 /)$.

\begin{abstract}
Background and Objectives: Abnormal expressions of CD74 and human leukocyte antigen-DR alpha (HLA-DRA) have been reported in various cancers, though their roles in cervical cancer remain unclear. This study aimed to evaluate the gene and protein expressions of CD74 and HLA-DRA in the progression from normal cervix to precancerous cervical intraepithelial neoplasia (CIN) and finally to squamous cell carcinoma (SCC). Materials and Methods: The gene expression profiles of CD74 and HLA-DRA were determined in formalin-fixed paraffin-embedded tissues, with three samples each from normal cervixes, human papillomavirus type 16/18-positive, low-grade CIN (LGCIN), high-grade CIN (HGCIN), and squamous cell carcinoma (SCC) using Human Transcriptome Array 2.0. Immunohistochemical expression of the proteins was semi-quantitatively assessed in another cohort of tissue microarray samples comprising 7 normal cervix cases, 10 LGCIN, 10 HGCIN, and 95 SCC. Results: The transcriptomics profile and proteins' expression demonstrated similar trends of upregulation of CD74 and HLA-DRA from normal cervix to CIN and highest in SCC. There was a significant difference in both proteins' expression between the histological groups ( $p=0.0001)$. CD74 and HLA-DRA expressions were significantly associated with CIN grade $(p=0.001$ and $p=0.030$, respectively) but not with the subjects' age or SCC stage. Further analysis revealed a positive correlation between CD74 and HLA-DRA proteins. Conclusions: CD74 appears to promote cervical carcinogenesis via oncogenic signalling mechanisms and may serve as a potential antitumour target. Additionally, the upregulation of HLA-DRA, often associated with stronger immunogenicity, could be a promising biomarker for developing immunotherapies.
\end{abstract}

Keywords: CD74; HLA-DRA; cervical cancer; cervical intraepithelial neoplasia

\section{Introduction}

Cervical cancer is the fourth most common cancer and the fourth leading cause of cancer death in women worldwide [1]. The analysis of cancer biomarkers that can be differentially expressed in the presence of this severe disease is an enormous challenge for researchers. Despite routine cytological screening programmes and the availability of multiple modalities of treatment, late-stage disease is associated with a poor outcome [2,3]. There is an urgent need to develop novel molecular therapeutic targets for the treatment of precancerous lesions and cervical cancer to reduce its mortality. Human papillomavirus (HPV), the causative factor in 90\% of cervical cancers [4], integrates into host cervical cells and causes molecular alterations that result in cell proliferation and the impairment of apoptosis and DNA repair mechanisms. Hence, the progression of HPV-infected cells into cervical intraepithelial neoplasia (CIN) and finally into invasive cancer [5].

Major histocompatibility complex (MHC) class II proteins specialise in the presentation of peptide antigens to CD4+ T cells [6]. Though MHC-II molecules are predominantly expressed by professional antigen-presenting cells, such as dendritic cells, B cells, and 
macrophages, recent evidence shows that a variety of tumours also express them, including breast cancer [7,8], colorectal cancer [9,10], ovarian cancer [11], and melanoma [12]. CD74 is the membrane form of the MHC class II invariant chain (Ii). When MHC class IICD74 complexes are formed, they are rapidly internalised to the endoplasmic reticulum for reloading with peptides to be recycled to the cell surface, triggering the adaptive immune response $[13,14]$. Recently, CD74 has been described as having an oncogenic role in promoting cell proliferation and preventing cell death via a macrophage migratory inhibitory factor (MIF)-dependent manner [15], as proven in breast cancer [16], renal cell carcinoma [17], colorectal cancer [18], and non-small-cell lung carcinoma [19].

HLA-DR is involved in the suppression of tumour growth, whereby it presents tumourassociated antigens (TAA) that are recognised by CD4+ T cells, which then produce cytokines, such as interleukins and interferon- $\gamma$ (IFN- $\gamma)$, to inhibit tumour growth $[20,21]$. Conflicting results have been reported on the expression of HLA-DRA in various cancers. Overexpression of HLA-DRA was demonstrated in colorectal cancer [22], hepatocellular cancer [23], and ovarian cancer [24], while it was downregulated in breast cancer [8]. HLA-DRA has also been shown to act as a prognostic marker for clinical outcomes $[13,25]$.

The roles of CD74 and HLA-DRA in cervical cancer development are relatively unknown. We aimed to evaluate the gene and protein expressions of these molecules in the progression from normal cervix to precancerous cervical intraepithelial neoplasia (CIN) and finally to squamous cell carcinomas (SCC), with the intent of exploring their potential use as therapeutic targets. To the best of our knowledge, this is the first report on the transcriptomic and protein expressions of these targets in the development of cervical cancer.

\section{Materials and Methods}

\subsection{Tissue Samples, RNA Extraction, Transcriptome Array}

Three cases each of human papillomavirus (HPV) 16/18-positive, low-grade cervical intraepithelial neoplasia (LGCIN), high-grade cervical intraepithelial neoplasia (HGCIN), squamous cell carcinoma (SCC), and HPV-negative normal cervixes were included in the study after approval by the Human Research Ethics Committee of Universiti Sains Malaysia, and in accordance with the Code of Ethics by the World Medical Association. Formalinfixed, paraffin-embedded tissue blocks were retrieved from the pathology department archives. HPV 16/18-positive samples were identified by immunohistochemistry with p16INK4a and HPV16 E6 + HPV18 E6 antibodies and real-time PCR. The areas of interest within the squamous epithelium were dissected using a ZEISS PALM Microbeam Laser Microdissection System (Carl Zeiss) from two $10 \mu \mathrm{m}$-thick tissue sections. Then, total RNA was extracted from the tissues with RNeasy FFPE extraction kit (Qiagen, Hilden, Germany). GeneChip Human Transcriptome Array 2.0 (HTA 2.0) (Affymetrix, Santa Clara, CA, USA) was used to profile the gene signatures of the four histological groups. Sensation plus FFPE WT kit (Affymetrix, Santa Clara, CA, USA) was used according to the manufacturer's protocol. Upon hybridisation, the chip was scanned using Affymetrix GeneChip Scanner 3000. The data were analysed with Affymetrix GeneChip Operating Software (GCOS), which contains qualitative and quantitative analysis for every probe set. Affymetrix Transcriptome Analysis Console (TAC) software was used to determine CD74 and HLA-DRA transcriptomic profiles in each histological group compared to a normal cervix. The methodology workflow is illustrated in Figure 1.

\subsection{Immunohistochemical Expression of $C D 74$ and HLA-DRA Proteins in Tissue Microarrays}

Immunohistochemistry (IHC) for each protein was performed on 2 tissue microarrays (TMA) (BB10011 and CR1101, Biomax, Rockville, MD, USA) comprising 10 cases of normal cervixes, 10 LGCIN, 11 HGCIN, and 98 squamous carcinoma cases. The TMAs had accompanying data on pathology diagnosis, CIN grade (Bethesda Classification System), and International Federation of Gynecology and Obstetrics (FIGO) staging for cervical cancer cases. 


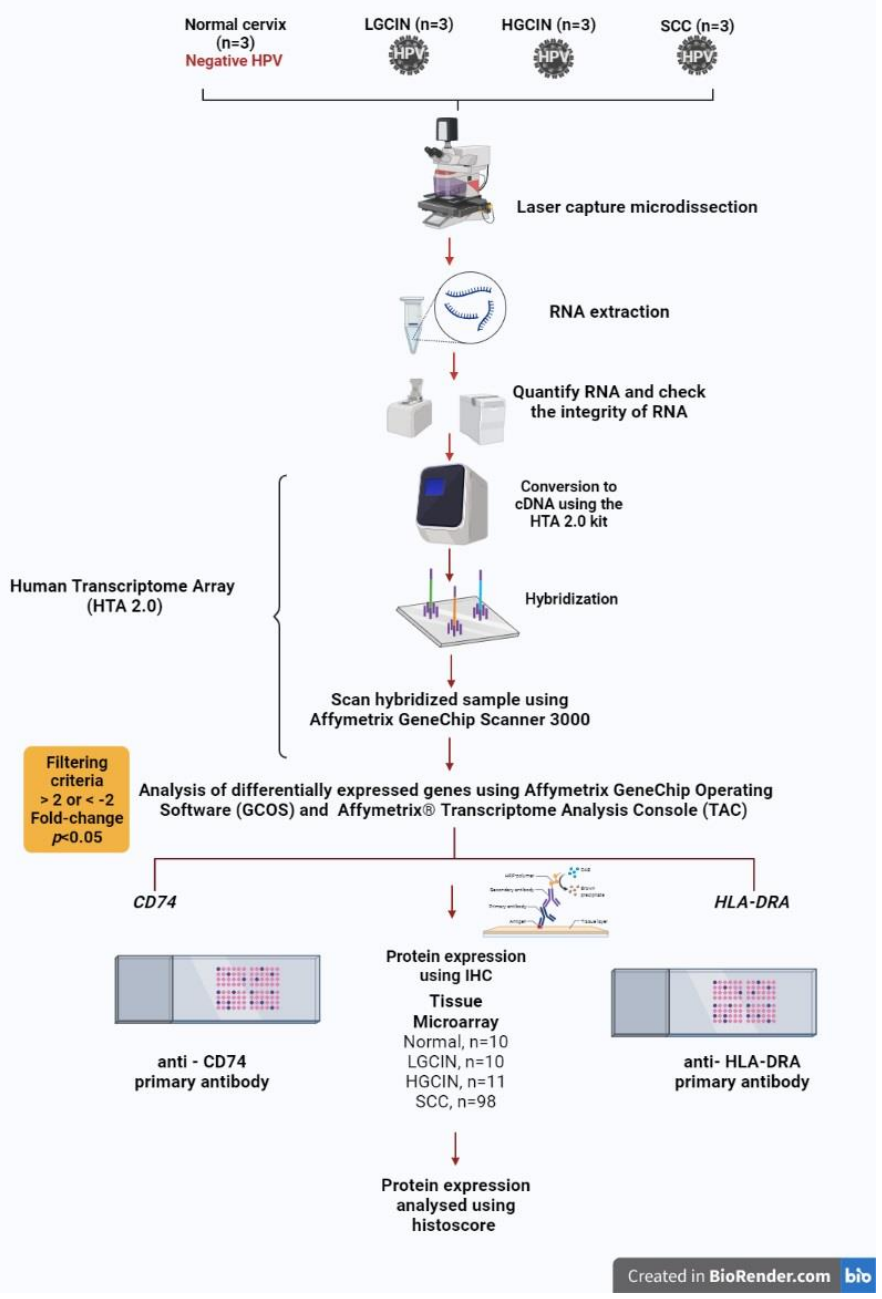

Figure 1. Methodology workflow of the study.

IHC was performed using the horseradish peroxidase polymer method from EnVision $^{\text {TM }}$ FLEX/HRP (Dako, Via Real Carpinteria, CA, USA). After the TMA slides were dewaxed and rehydrated, they were immersed in EnVision ${ }^{\mathrm{TM}}$ FLEX target retrieval solution (50× Tris/EDTA buffer, $\mathrm{pH} 9$ ) and in a microwave oven (Panasonic) under a low setting for $20 \mathrm{~min}$. Subsequently, the slides were incubated with a few drops of EnVision ${ }^{\mathrm{TM}}$ FLEX Peroxidase solution for $5 \mathrm{~min}$, followed by a rinse. Rabbit polyclonal anti-CD74 antibody (1:500 dilution; cat. no. HPA010592, Sigma-Aldrich, St. Louis, MO, USA) or rabbit polyclonal anti-HLA-DRA antibody (1:1000 dilution; cat. no. HPA053176, SigmaAldrich, USA) was applied and incubated overnight at $4{ }^{\circ} \mathrm{C}$. After rinsing, EnVision ${ }^{\mathrm{TM}}$ FLEX/HRP secondary antibody was added and incubated for 20 min followed by EnVision $^{\mathrm{TM}}$ FLEX substrate working solution (EnVision ${ }^{\mathrm{TM}}$ FLEX substrate buffer mixed with EnVision $^{\mathrm{TM}}$ FLEX DAB + chromogen) for 5 min. Slides were counterstained with Mayer's haematoxylin for $5 \mathrm{~min}$. The slides were rinsed thrice with EnVision ${ }^{\mathrm{TM}}$ FLEX Wash Buffer for 5 min each between the incubation steps above. Finally, the slides were dried, mounted, and viewed under a light microscope before they were scanned with a Pannoramic Digital Slide Scanner (3DHISTECH Ltd., Budapest, Öv u. 3., Hungary). The digital slides from whole slide imaging were analysed using Case Viewer software. Brown staining signified positive protein expression. The histoscore was calculated by multiplying the percentage of the positivity score and staining intensity score, as shown in Table 1. Tonsil tissue was used as a positive control, where brown staining was observed in lymphocytes of lymphoid follicle germinal centres. Primary antibodies were omitted in the negative control. 
Table 1. Semi-quantitative scoring for immunohistochemical expression of CD74 and HLA-DRA proteins.

\begin{tabular}{llll}
\hline Percentage of Positive Cells & Score & Staining Intensity & Score \\
\hline$<1 \%$ positive cells & 0 & No staining & 0 \\
$1-25 \%$ positive cells & 1 & Weak staining & 1 \\
$26-50 \%$ positive cells & 2 & Moderate staining & 2 \\
$51-75 \%$ positive cells & 3 & Strong staining & 3 \\
$\geq 75 \%$ positive cells & 4 & & \\
\hline
\end{tabular}

Final score $=$ percentage of positive cells score $\times$ staining intensity score.

Final histoscore: $0=$ negative.

1 to $3 / 12$ = low expression.

$\geq 4 / 12$ = high expression.

\subsection{Statistical Analysis}

Transcriptomic analysis in HTA 2.0 was performed by comparing the gene expression in each histological group to normal cervixes, using a one-way ANOVA test provided by the array software, with a significance set at a $p$ value $<0.05$. The association between CD74 and HLA-DRA histoscore and histological groups as well as clinicopathological parameters was analysed by the Pearson chi-square test with the significance set at a $p$ value $<0.05$, using the IBM SPSS v26.0 software package for Windows. Further analysis of the correlation between CD74 and HLA-DRA protein expression was calculated using Spearman's rank correlation with the significance at a $p$ value $<0.01$.

\section{Results}

\subsection{Transcriptomics Profile}

The transcriptomic profile of CD74 and HLA-DRA genes was compared between each histological group (LGCIN, HGCIN, and SCC) and the normal cervixes. The differences in fold change are shown in Figure 2. The results demonstrate an increasing trend in upregulation in both genes, from LGCIN to HGCIN and highest in SCC. The difference in fold change was minimal in LGCIN compared to normal cervixes (1.24 for HLA-DRA and 1.35 for CD74). As the disease progressed, the genes were increasingly upregulated. The HLA-DRA gene showed a 9.44-fold change in HGCIN and a 12.57-fold change in SCC, while the CD74 gene revealed a 4.34-fold change in HGCIN and a 6.28-fold change in SCC, compared to the normal cervixes. However, it should be noted that the fold change differences were not statistically significant.

\subsection{Immunohistochemistry}

The CD74 and HLA-DRA proteins' expressions were scored on 122 cases comprising 7 normal cervixes, 10 LGCIN, 10 HGCIN, and 95 SCC cases. Seven tissue cores were excluded due to the absence of squamous cells. We noted that both proteins were localised in the cytoplasm and membrane of squamous cells. Stromal inflammatory cells and endothelial cells of blood vessels were positively stained. The association between protein histoscore and histological groups as well as clinicopathological parameters are tabulated in Tables 2 and 3. Both CD74 and HLA-DRA immunohistochemical expressions were significantly different between the histological groups $(p=0.0001)$ and in SCC compared to normal cervixes $(p=0.0001)$. Additionally, the CD74 expression was significantly different in HGCIN compared to the normal cervixes $(p=0.006)$, and HLA-DRA was differently expressed in LGCIN compared to the normal cervixes $(p=0.001)$. Both proteins showed significant association with CIN grade, but not with the subject's age or SCC stage. The correlation coefficient (rs) of CD74 and HLA-DRA expression was $0.76, p=0.0001$, reflecting a positive correlation between the two proteins. Representative immunohistochemical staining patterns are shown in Figure 3. 


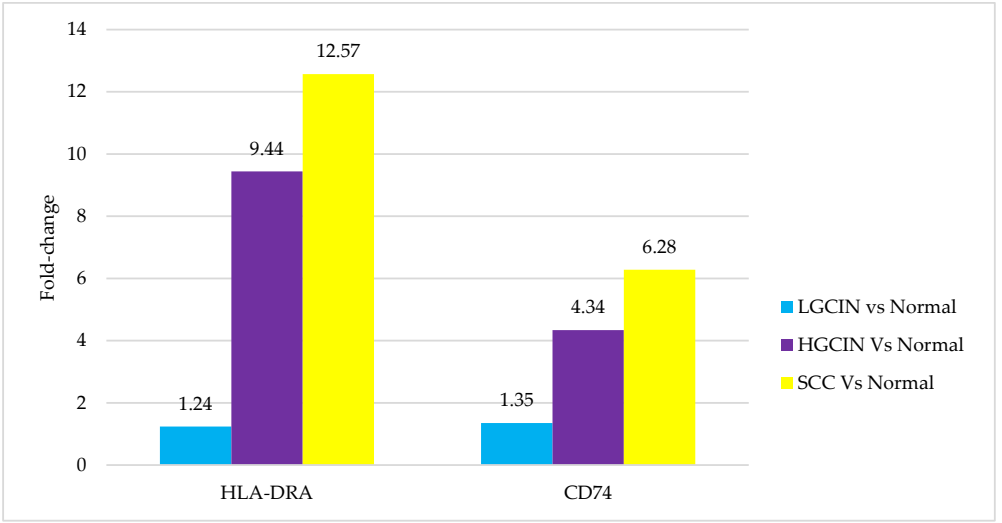

Figure 2. Transcriptomic profiles of HLA-DRA and CD74 in LGCIN, HGCIN, and SCC obtained from Human Transcriptome Array. Bars represent the fold change difference in each histological group compared to the normal cervix. The fold changes were not significant by one-way ANOVA where $p>0.05$.

Table 2. Comparison of CD74 and HLA-DRA histoscores between the histological groups.

\begin{tabular}{|c|c|c|c|c|c|c|}
\hline & Histoscore & & & & & \\
\hline $\begin{array}{l}\text { Histological } \\
\text { Group }\end{array}$ & $\begin{array}{l}\text { Negative } \\
n(\%)\end{array}$ & $\begin{array}{l}\text { Low } \\
n(\%)\end{array}$ & $\begin{array}{l}\text { High } \\
n(\%)\end{array}$ & Total $n(\%)$ & $\begin{array}{l}\text { Comparison between All } \\
\text { Histological Groups } \\
p \text { Value }\end{array}$ & $\begin{array}{l}\text { Histological Group vs. } \\
\text { Normal Cervix } \\
p \text { Value }\end{array}$ \\
\hline \multicolumn{7}{|l|}{ CD74 protein } \\
\hline Normal cervix & $4(57.1)$ & $2(28.6)$ & $1(14.3)$ & $7(100)$ & \multirow{5}{*}{0.0001} & \\
\hline LGCIN & $4(40.0)$ & $5(50.0)$ & $1(10.0)$ & $10(100)$ & & 0.798 \\
\hline HGCIN & $1(10.0)$ & $0(0.0)$ & $9(90.0)$ & $10(100)$ & & 0.006 \\
\hline SCC & $5(5.3)$ & $7(7.4)$ & $83(87.4)$ & $95(100)$ & & 0.0001 \\
\hline Total & $14(11.5)$ & $14(11.5)$ & $94(77.0)$ & $122(100)$ & & \\
\hline \multicolumn{7}{|c|}{ HLA-DRA protein } \\
\hline Normal cervix & $0(0.0)$ & $6(85.7)$ & $1(14.3)$ & $7(100)$ & \multirow{5}{*}{0.0001} & \multirow{5}{*}{$\begin{array}{l}0.001 \\
0.464 \\
0.0001\end{array}$} \\
\hline LGCIN & $8(80.0)$ & $1(10.0)$ & $1(10.0)$ & $10(100)$ & & \\
\hline HGCIN & $2(20.0)$ & $5(50.0)$ & $3(30.0)$ & $10(100)$ & & \\
\hline SCC & $6(6.3)$ & $5(5.3)$ & $84(88.4)$ & $95(100)$ & & \\
\hline Total & $16(13.1)$ & $17(13.9)$ & $89(73.0)$ & $122(100)$ & & \\
\hline
\end{tabular}

Chi-square test, statistical significance set at $p$ value $<0.05$.

Table 3. The association between CD74 and HLA-DRA proteins expression with demographic and clinicopathological parameters.

\begin{tabular}{|c|c|c|c|c|c|c|c|c|c|c|}
\hline \multirow[b]{2}{*}{ Parameters } & \multicolumn{3}{|c|}{ CD74 Histoscore } & \multirow[b]{2}{*}{$\begin{array}{l}\text { Total } \\
n(\%)\end{array}$} & \multirow[b]{2}{*}{$p$ Value } & \multicolumn{3}{|c|}{ HLA-DRA Histoscore } & \multirow[b]{2}{*}{$\begin{array}{l}\text { Total } \\
n(\%)\end{array}$} & \multirow[b]{2}{*}{$p$ Value } \\
\hline & $\begin{array}{c}\text { Negative } \\
n(\%)\end{array}$ & $\begin{array}{c}\text { Low } \\
n(\%)\end{array}$ & $\begin{array}{l}\text { High } \\
n(\%)\end{array}$ & & & $\begin{array}{c}\text { Negative } \\
n(\%)\end{array}$ & $\begin{array}{c}\text { Low } \\
n(\%)\end{array}$ & $\begin{array}{l}\text { High } \\
n(\%)\end{array}$ & & \\
\hline \multicolumn{11}{|l|}{ Age (years) } \\
\hline$<50$ & $4(5.8)$ & $8(11.6)$ & $57(82.6)$ & $69(100)$ & \multirow[t]{3}{*}{0.083} & $10(14.5)$ & $10(14.5)$ & $49(71.0)$ & $69(100)$ & \multirow[t]{3}{*}{0.838} \\
\hline$\geq 50$ & $10(18.9)$ & $4(7.5)$ & $39(73.6)$ & $53(100)$ & & $6(11.3)$ & $7(13.2)$ & $40(75.5)$ & $53(100)$ & \\
\hline$\overline{\mathrm{C}} \mathrm{IN}$ grade & & & & & & & & & & \\
\hline LGCIN & $4(40.0)$ & $5(50.0)$ & $1(10.0)$ & $10(100)$ & \multirow[t]{3}{*}{0.001} & $8(80.0)$ & $1(10.0)$ & $1(10.0)$ & $10(100)$ & \multirow[t]{3}{*}{0.030} \\
\hline HGCIN & $1(10.0)$ & $0(0.0)$ & $9(90.0)$ & $10(100)$ & & $2(20.0)$ & $5(50.0)$ & $3(30.0)$ & $10(100)$ & \\
\hline SCC stage & & & & & & & & & & \\
\hline Stage I & $0(0.0)$ & $2(6.7)$ & $28(93.3)$ & $30(100)$ & \multirow{9}{*}{0.790} & $1(3.3)$ & $0(0.0)$ & $29(96.7)$ & $30(100)$ & \multirow{9}{*}{0.753} \\
\hline Stage IA & $0(0.0)$ & $0(0.0)$ & $1(100.0)$ & $1(100)$ & & $0(0.0)$ & $0(0.0)$ & $1(100)$ & $1(100)$ & \\
\hline Stage IB & $3(15.0)$ & $2(10.0)$ & $15(75.0)$ & $20(100)$ & & $2(10.0)$ & $2(10.0)$ & $16(80.0)$ & $20(100)$ & \\
\hline Stage IC & $0(0.0)$ & $0(0.0)$ & $1(100.0)$ & $1(100)$ & & $0(0.0)$ & $0(0.0)$ & $1(100)$ & $1(100)$ & \\
\hline Stage II & $0(0.0)$ & 1 (16.7) & $5(83.3)$ & $6(100)$ & & $0(0.0)$ & $0(0.0)$ & $6(100)$ & $6(100)$ & \\
\hline Stage IIA & $1(5.3)$ & $1(5.3)$ & $17(89.5)$ & 19 (100) & & $1(5.3)$ & $1(5.3)$ & $17(89.5)$ & 19 (100) & \\
\hline Stage IIB & $1(8.3)$ & $1(8.3)$ & $10(83.3)$ & 12 (100) & & 2 (16.7) & $1(8.3)$ & $9(75.0)$ & 12 (100) & \\
\hline Stage III & $0(0.0)$ & $0(0.0)$ & $1(100.0)$ & $1(100)$ & & $1(3.3)$ & $0(0.0)$ & $29(96.7)$ & 30 (100) & \\
\hline Stage IIIB & $0(0.0)$ & $0(0.0)$ & $4(100.0)$ & $4(100)$ & & $0(0.0)$ & $0(0.0)$ & $1(100)$ & $1(100)$ & \\
\hline
\end{tabular}




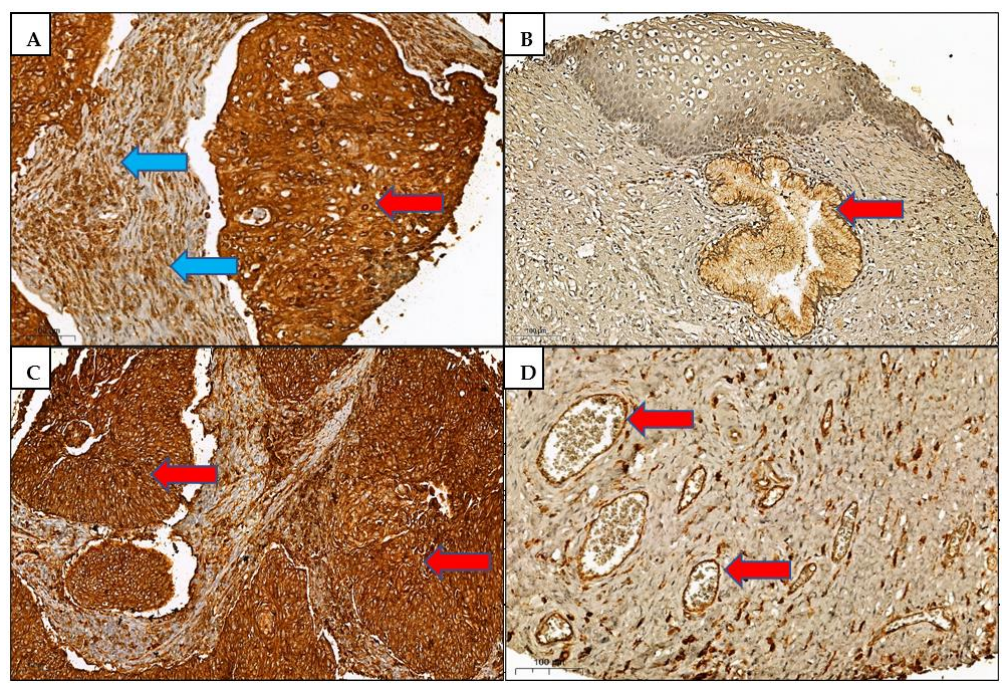

Figure 3. Immunohistochemical expression patterns in tissue microarrays. (A) CD74 high histoscore in cytoplasm/membrane of SCC cells (red arrow) and stromal lymphocytes (blue arrows). (B) Absent CD74 expression in normal squamous cells and low expression in normal endocervical cells (red arrow). (C) HLA-DRA high histoscore in cytoplasm/membrane of SCC cells (red arrows). (D) HLA-DRA positivity in endothelial cells of small blood vessels (red arrows). Scale bar: $100 \mu \mathrm{m}$.

\section{Discussion}

The progression of HPV-infected cervical cells into a distinctive precancerous stage (CIN) and finally into SCC offers a unique advantage to study the roles of CD74 and HLADRA molecules in cervical carcinogenesis. Numerous reports suggest these molecules are involved in the pathogenesis of various cancers. This is the first study elucidating the possible roles of these target genes and proteins in cervical cancer development. CD74 is believed to exert an oncogenic effect. The present study demonstrated an increasing trend in CD74 gene and protein expression, being lowest in normal cervixes, higher in CIN, and highest in the SCC group (Figure 2 and Table 1). These findings are in concordance with another report of higher CD74 protein expression in CIN lesions compared to normal cervixes and higher in SCC than in CIN [26]. An increased expression of CD74 in human colorectal adenomas was found to be related to an ascending grade of epithelial cell dysplasia, corresponding to the CIN stage in our study [27]. Furthermore, CD74 immunohistochemical expression increased in higher-grade and late-stage metastatic invasive cancers compared to less aggressive and lower-grade cancers, as reported in thymic epithelial neoplasms [28], colorectal, gastric, and pancreatic cancers [29], and urothelial carcinoma of the bladder [17]. The presence of CD74 protein on tumour cells membranes and cytoplasm in our study suggests an interaction with macrophage migratory inhibitory factor (MIF) and internalisation of CD74, in agreement with other studies [16,17,28].

In our study, CD74 expression was not associated with the patient's age $(p=0.083)$ or SCC stage $(p=0.790)$ (Table 3$)$. There are no published reports in the literature on these traits in cervical cancer. However, in urothelial carcinomas of the bladder, there was a correlation with older subjects and an advanced stage of disease [17]. Further analysis of a larger cohort is necessary to gain an insight into the possible predictive role of CD74 in cervical cancer in different patient age groups and cancer stages.

The upregulation of CD74 in many types of cancers suggests its role in facilitating tumour progression and metastasis. Upon stimulation by the migration inhibitory factor (MIF), CD74 coupled with CD44 can induce phosphorylation and activation of Src and ERK1/2, as well as p53 dephosphorylation, eventually promoting cell proliferation and inhibiting apoptosis $[14,30]$. Persistent overexpression of CD74 on the cell surface could impair MHC class II antigen presentation by tumour cells, thereby contributing to immune escape and promoting tumour metastasis [15]. It has also been demonstrated that CD74's 
cytoplasmic domain binds chromatin and regulates the transcription and expression of genes involved in immune regulation, cell survival, and hematopoietic cancers [31]. CD74 may have a potential role in targeted cancer therapy, using monoclonal antibodies or small molecules to block CD74 function [15].

In the present study, HLA-DRA gene expression was lowest in LGCIN and highest in SCC, compared to normal cervixes (Figure 1), correlating with the immunohistochemistry results, with absent expression in $80 \%$ of LGCIN cases and highly expressed in $88.4 \%$ of SCC cases (Table 2). The findings suggest immune escape, which would promote the proliferation of HPV-infected cells in the LGCIN stage. As the disease progresses to HGCIN and SCC, increased synthesis of HLA-DRA protein recruits immune support via CD4+ $\mathrm{T}$ cells, leading to more favourable CD8+ T-cells responses and thus preventing tumour invasion. This finding parallels a previous study using the same sample cohort that revealed deregulation of the immune-related genes, including MHC II and immunoglobulin heavy chain genes in the progression from LGCIN to HGCIN and SCC [32].

The precise role of HLA class II in cancer is poorly understood, reflected by conflicting reports on its protein expression in various cancers. Strong HLA-DR expression has been demonstrated in colorectal cancer tissues and was related to a better prognosis [22], similarly in ovarian cancer [33], and consistent with our study. An upregulation of HLA-DRA expression is associated with antitumour immune response, whereby it functions in presenting tumour-associated antigens (TAA) on cancer cells that trigger CD4+ Th1 cells and NK cells, with the production of IFN- $\gamma$, an antitumour cytokine. A causative relationship has been found between MHC-II and/or HLA-DRA and increased tumour-infiltrating lymphocytes, associated with more favourable outcomes in cancer patients [13,25,34]. However, it is still unclear whether this type of immune response determines the rate of tumour progression or an impression of ongoing elimination or equilibrium phases of cancer immunoediting [35]. In our study, HLA-DRA expression was not associated with the SCC stage $(p=0.753)$ (Table 3). Additionally, we could not evaluate the amount of tumour-infiltrating lymphocytes in the small tissue cores. The therapeutic implications of tumour-specific MHC-II (tsMHC-II) are promising, wherein their upregulation correlates with a better response to an anti-PD-1 monoclonal antibody in Hodgkin lymphoma and melanoma [12,36], and therefore offering opportunities as a biomarker in the development of immunotherapies [13,25]. Additional studies are required to evaluate the role of MHC-II and PD-1/PD-L1 to predict the treatment response in cervical cancer.

In contrast, downregulation of HLA-DR is associated with an unfavourable outcome and aggressiveness in breast cancer [8], diffuse large B cell lymphoma [37], and smallcell lung carcinoma (SCLC) compared to non-SCLC [38]. A low expression observed in hepatocellular carcinoma was linked to early intrahepatic recurrence [23]. Repression of tumour-specific MHC-II molecules in cancers, often by hypermethylation or hypoacetylation of promoters of HLA genes and/or class II transactivator (CIITA), causes a reduction in T helper 1 (Th 1) cytokines such as IFN- $\gamma$ and TNF $\alpha$, which inhibit the activation of CD8+ cytotoxic T cells, eventually leading to a loss of tumour immunosurveillance $[13,25,37,39]$.

The positive correlation between the CD74 and HLA-DRA expression in our study was also found in another report on invasive thymomas [28]. This suggests that overexpressed CD74 did not affect the antigen presentation machinery of HLA-DRA. In contradiction, CD74 or the invariant chain (Ii) expression was negatively correlated with HLA-DR expression in gastric cancer [40] and breast carcinoma [41]. This may be due to superinduction of Ii affecting tumour antigen presentation by MHC-II molecules, contributing to immune evasion and tumour metastasis [42].

Notwithstanding the small number of clinical samples used in transcriptomics analysis, the method used is sensitive, and the results clearly indicated an upward trend of CD74 and HLA-DRA gene expression from normal cervixes to CIN and SCC. The validation by protein expression analysis in a large adequate sample size supported these findings. 


\section{Conclusions}

Our findings suggest that $\mathrm{CD} 74$ protein promotes cervical carcinogenesis via oncogenic signalling mechanisms and could be potentially useful for antitumour therapy. CD74 may facilitate HLA-DR internalisation to trigger stronger immunogenicity against tumours. HLA-DRA may aid as a prognostic biomarker and play a possible role in immunotherapy. Our hypotheses of the possible effects of CD74 and HLA-DRA are illustrated in Figure 4. Future trends incorporating high throughput analysis of gene and protein expression in tandem with patients' clinical outcomes will lead to the discovery of potential targets for immunotherapy and targeted therapy directed towards precision medicine.

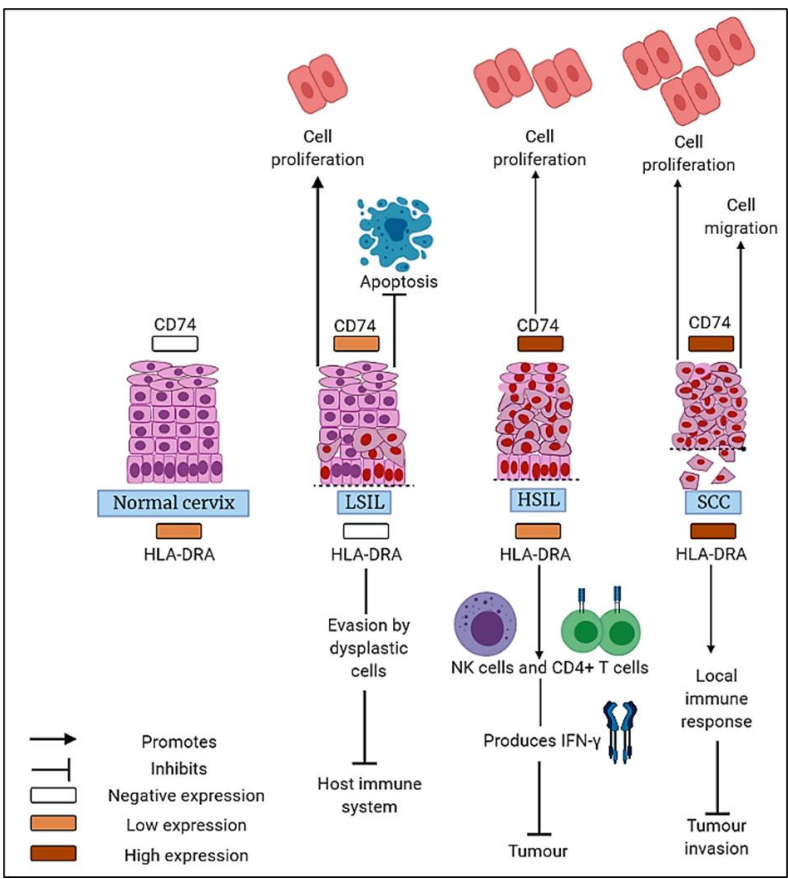

Figure 4. Summary of results illustrating CD74 and HLA-DRA expression patterns and their potential roles in the development of cervical cancer.

Author Contributions: Conceptualisation, G.K.; methodology, C.K.B. and S.D.B.; validation, G.K.; formal analysis, C.K.B. and S.D.B.; writing—original draft preparation, C.K.B. and G.K.; writing-review and editing, G.K. and G.J.T.; supervision, G.K.; project administration, G.K.; funding acquisition, G.K. All authors have read and agreed to the published version of the manuscript.

Funding: This research was funded by the Ministry of Higher Education Malaysia for Fundamental Research Grant Scheme Reference Code: FRGS/1/2019/SKK13/USM/01/1.

Institutional Review Board Statement: The study was conducted in accordance with the Declaration of Helsinki, and the transcriptomics profiling part of the study was approved by the Human Research Ethics Committee of Universiti Sains Malaysia (USM/JEPeM/279.3 (1) and the Joint Ethics Committee of USM-Hospital Lam Wah Ee, Malaysia (USM-HLWE/IEC/2014 (0008).

Informed Consent Statement: Patient consent was waived due to samples consisting of archival tissue blocks only, retrieved from the pathology department.

Data Availability Statement: The datasets generated during and/or analysed during the current study are available from the corresponding author on reasonable request.

Conflicts of Interest: The authors declare no conflict of interest. The funders had no role in the design of the study; in the collection, analyses, or interpretation of data; in the writing of the manuscript, or in the decision to publish the results. 


\section{References}

1. Sung, H.; Ferlay, J.; Siegel, R.L.; Laversanne, M.; Soerjomataram, I.; Jemal, A.; Bray, F. Global Cancer Statistics 2020: GLOBOCAN Estimates of Incidence and Mortality Worldwide for 36 Cancers in 185 Countries. CA Cancer J. Clin. 2021, 71, 209-249. [CrossRef]

2. Mallmann, P.; Mallmann, C. Neoadjuvant and Adjuvant Chemotherapy of Cervical Cancer. Oncol. Res. Treat. 2016, 39, 522-524. [CrossRef] [PubMed]

3. Cohen, P.A.; Jhingran, A.; Oaknin, A.; Denny, L. Cervical cancer. Lancet 2019, 393, 169-182. [CrossRef]

4. Burd, E.M. Human papillomavirus and cervical cancer. Clin. Microbiol. Rev. 2003, 16, 1-17. [CrossRef] [PubMed]

5. Balasubramaniam, S.D.; Balakrishnan, V.; Oon, C.E.; Kaur, G. Key molecular events in cervical cancer development. Medicina 2019, 55, 384. [CrossRef] [PubMed]

6. Neefjes, J.; Jongsma, M.L.M.; Paul, P.; Bakke, O. Towards a systems understanding of MHC class i and MHC class II antigen presentation. Nat. Rev. Immunol. 2011, 11, 823-836. [CrossRef]

7. Park, I.A.; Hwang, S.-H.; Song, I.H.; Heo, S.-H.; Kim, Y.-A.; Bang, W.S.; Park, H.S.; Lee, M.; Gong, G.; Lee, H.J. Expression of the MHC class II in triple-negative breast cancer is associated with tumor-infiltrating lymphocytes and interferon signaling. PLoS ONE 2017, 12, e0182786. [CrossRef]

8. Da Silva, G.B.R.F.; Silva, T.G.A.; Duarte, R.A.; Neto, N.L.; Carrara, H.H.A.; Donadi, E.A.; Gonçalves, M.A.G.; Soares, E.G.; Soares, C.P. Expression of the Classical and Nonclassical HLA Molecules in Breast Cancer. Int. J. Breast Cancer 2013, $2013,250435$. [CrossRef]

9. Michel, S.; Linnebacher, M.; Alcaniz, J.; Voss, M.; Wagner, R.; Dippold, W.; Becker, C.; Doeberitz, M.V.K.; Ferrone, S.; Kloor, M. Lack of HLA class II antigen expression in microsatellite unstable colorectal carcinomas is caused by mutations in HLA class II regulatory genes. Int. J. Cancer 2010, 127, 889-898. [CrossRef]

10. Warabi, M.; Kitagawa, M.; Hirokawa, K. Loss of MHC class II expression is associated with a decrease of tumor-infiltrating T cells and an increase of metastatic potential of colorectal cancer: Immunohistological and histopathological analyses as compared with normal colonic mucosa and adenomas. Pathol. Res. Pract. 2000, 196, 807-815. [CrossRef]

11. Kübler, K.; Arndt, P.F.; Wardelmann, E.; Krebs, D.; Kuhn, W.; Van Der Ven, K. HLA-class II haplotype associations with ovarian cancer. Int. J. Cancer 2006, 119, 2980-2985. [CrossRef] [PubMed]

12. Johnson, D.B.; Bordeaux, J.M.; Kim, J.-Y.; Vaupel, C.A.; Rimm, D.L.; Ho, T.H.; Joseph, R.W.; Daud, A.; Conry, R.M.; Gaughan, E.M.; et al. Quantitative spatial profiling of PD-1/PD-L1 interaction and HLA-DR/IDO-1 predicts improved outcomes of anti-PD-1 therapies in metastatic melanoma. Clin. Cancer Res. 2018, 24, 5250-5260. [CrossRef] [PubMed]

13. Axelrod, M.L.; Cook, R.S.; Johnson, D.B.; Balko, J.M. Biological consequences of MHC-II expression by tumor cells in cancer. Clin. Cancer Res. 2019, 25, 2392-2402. [CrossRef] [PubMed]

14. Karakikes, I.; Morrison, I.E.G.; O’Toole, P.; Metodieva, G.; Navarrete, C.V.; Gomez, J.; Miranda-Sayago, J.M.; Cherry, R.J.; Metodiev, M.; Fernandez, N. Interaction of HLA-DR and CD74 at the cell surface of antigen-presenting cells by single particle image analysis. FASEB J. 2012, 26, 4886-4896. [CrossRef] [PubMed]

15. Liu, Y.-H.; Lin, J.-Y. Recent advances of cluster of differentiation 74 in cancer. World J. Immunol. 2014, 4, 174. [CrossRef]

16. Tian, B.; Zhang, Y.; Li, N.; Liu, X.; Dong, J. CD74: A potential novel target for triple-negative breast cancer. Tumour Biol. 2012, 33, 2273-2277. [CrossRef]

17. Choi, J.W.; Kim, Y.; Lee, J.H.; Kim, Y.S. CD74 expression is increased in high-grade, invasive urothelial carcinoma of the bladder. Int. J. Urol. 2013, 20, 251-255. [CrossRef]

18. Rossi, H.A.; Liu, Q.; Banner, B.; Hsieh, C.C.; Savas, L.; Savarese, D. The prognostic value of invariant chain (Ii) and Her-2/neu expression in curatively resected colorectal cancer. Cancer J. 2002, 8, 268-275. [CrossRef]

19. Matsuura, S.; Shinmura, K.; Kamo, T.; Igarashi, H.; Maruyama, K.; Tajima, M.; Ogawa, H.; Tanahashi, M.; Niwa, H.; Funai, K.; et al. CD74-ROS1 fusion transcripts in resected non-small cell lung carcinoma. Oncol. Rep. 2013, 30, 1675-1680. [CrossRef]

20. Sabbatino, F.; Liguori, L.; Polcaro, G.; Salvato, I.; Caramori, G.; Salzano, F.A.; Casolaro, V.; Stellato, C.; Col, J.D.; Pepe, S. Role of human leukocyte antigen system as a predictive biomarker for checkpoint-based immunotherapy in cancer patients. Int. J. Mol. Sci. 2020, 21, 7295. [CrossRef]

21. Seliger, B.; Kloor, M.; Ferrone, S. HLA class II antigen-processing pathway in tumors: Molecular defects and clinical relevance. Oncoimmunology 2017, 6, e1171447. [CrossRef] [PubMed]

22. Matsushita, K.; Takenouchi, T.; Shimada, H.; Tomonaga, T.; Hayashi, H.; Shioya, A.; Komatsu, A.; Matsubara, H.; Ochiai, T. Strong HLA-DR antigen expression on cancer cells relates to better prognosis of colorectal cancer patients: Possible involvement of c-myc suppression by interferon- $\gamma$ in situ. Cancer Sci. 2006, 97, 57-63. [CrossRef] [PubMed]

23. Matoba, K.; Iizuka, N.; Gondo, T.; Ishihara, T.; Yamada-Okabe, H.; Tamesa, T.; Takemoto, N.; Hashimoto, K.; Sakamoto, K.; Miyamoto, T.; et al. Tumor HLA-DR expression linked to early intrahepatic recurrence of hepatocellular carcinoma. Int. J. Cancer 2005, 115, 231-240. [CrossRef] [PubMed]

24. Daltoé, R.D.; Madeira, K.P.; de Araújo, K.L.; Lyra, P.C.M., Jr.; Tessarollo, N.G.; de Souza, M.L.M.; dos Santos, D.Z.; de Carvalho, A.A.; Rotstein, C.; Lima, R.; et al. Clinical Relevance of Co-Expression of HLA-DR $\alpha$, CD74/II and NFkB in Epithelial Ovarian Cancer: Identification of Prognostic and Therapeutical Biomarker Profile. SL Clin. Med. Oncol. 2020, 2, 1-11.

25. Chamuleau, M.E.D.; Ossenkoppele, G.J.; van de Loosdrecht, A.A. MHC class II molecules in tumour immunology: Prognostic marker and target for immune modulation. Immunobiology 2006, 211, 619-625. [CrossRef] 
26. Cheng, R.J.; Deng, W.G.; Niu, C.B.; Li, Y.Y.; Fu, Y. Expression of macrophage migration inhibitory factor and CD74 in cervical squamous cell carcinoma. Int. J. Gynecol. Cancer 2011, 21, 1004-1012. [CrossRef]

27. Cuthbert, R.J.; Wilson, J.M.; Scott, N.; Coletta, P.L.; Hull, M.A. Differential CD74 (major histocompatibility complex Class II invariant chain) expression in mouse and human intestinal adenomas. Eur. J. Cancer 2009, 45, 1654-1663. [CrossRef]

28. Datta, M.W.; Shahsafaei, A.; Nadler, L.M.; Freeman, G.J.; Dorfman, D.M. Expression of MHC class II-associated invariant chain (Ii;CD74) in thymic epithelial neoplasms. Appl. Immunohistochem. Mol. Morphol. 2000, 8, 210-215. [CrossRef]

29. Gold, D.V.; Stein, R.; Burton, J.; Goldenberg, D.M. Enhanced expression of CD74 in gastrointestinal cancers and benign tissues. Int. J. Clin. Exp. Pathol. 2011, 4, 1-12.

30. Shi, X.; Leng, L.; Wang, T.; Wang, W.; Du, X.; Li, J.; McDonald, C.; Chen, Z.; Murphy, J.W.; Lolis, E.; et al. CD44 Is the Signaling Component of the Macrophage Migration Inhibitory Factor-CD74 Receptor Complex. Immunity 2006, 25, 595-606. [CrossRef]

31. Gil-Yarom, N.; Radomir, L.; Sever, L.; Kramer, M.P.; Lewinsky, H.; Bornstein, C.; Blecher-Gonen, R.; Barnett-Itzhaki, Z.; Mirkin, V.; Friedlander, G.; et al. CD74 is a novel transcription regulator. Proc. Natl. Acad. Sci. USA 2017, 114, 562-567. [CrossRef] [PubMed]

32. Balasubramaniam, S.D.; Wong, K.K.; Oon, C.E.; Balakrishnan, V.; Kaur, G. Comparative transcriptomic profiling in HPV-associated cervical carcinogenesis: Implication of MHC class II and immunoglobulin heavy chain genes. Life Sci. 2020, 256, 118026. [CrossRef] [PubMed]

33. Rangel, L.B.; Agarwal, R.; Sherman-Baust, C.A.; de Mello-Coelho, V.; Pizer, E.S.; Ji, H.; Taub, D.D.; Morin, P.J. Anomalous expression of the HLA-DR $\alpha$ and $\beta$ chains in ovarian and other cancers. Cancer Biol. Ther. 2004, 3, 1021-1027. [CrossRef] [PubMed]

34. Fan, X.; Liang, J.; Wu, Z.; Shan, X.; Qiao, H.; Jiang, T. Expression of HLA-DR genes in gliomas: Correlation with clinicopathological features and prognosis. Chin. Neurosurg. J. 2017, 3, 27. [CrossRef]

35. Schreiber, R.D.; Old, L.J.; Smyth, M.J. Cancer immunoediting: Integrating immunity's roles in cancer suppression and promotion. Science 2011, 331, 1565-1570. [CrossRef]

36. Roemer, M.G.; Redd, R.A.; Cader, F.Z.; Pak, C.J.; Abdelrahman, S.; Ouyang, J.; Sasse, S.; Younes, A.; Fanale, M.; Santoro, A.; et al. Major histocompatibility complex class II and programmed death ligand 1 expression predict outcome after programmed death 1 blockade in classic Hodgkin lymphoma. J. Clin. Oncol. 2018, 36, 942-950. [CrossRef]

37. Rimsza, L.M.; Roberts, R.A.; Miller, T.P.; Unger, J.M.; LeBlanc, M.; Braziel, R.M.; Weisenberger, D.D.; Chan, W.C.; MullerHermelink, H.K.; Jaffe, E.S.; et al. Loss of MHC class II gene and protein expression in diffuse large B-cell lymphoma is related to decreased tumor immunosurveillance and poor patient survival regardless of other prognostic factors: A follow-up study from the Leukemia and Lymphoma Molecular. Blood 2004, 103, 4251-4258. [CrossRef]

38. Yazawa, T.; Kamma, H.; Fujiwara, M.; Matsui, M.; Horiguchi, H.; Satoh, H.; Fujimoto, M.; Yokoyama, K.; Ogata, T. Lack of class II transactivator causes severe deficiency of HLA-DR expression in small cell lung cancer. J. Pathol. 1999, 187, 191-199. [CrossRef]

39. Cycon, K.A.; Mulvaney, K.; Rimsza, L.M.; Persky, D.; Murphy, S.P. Histone deacetylase inhibitors activate CIITA and MHC class II antigen expression in diffuse large B-cell lymphoma. Immunology 2013, 140, 259-272. [CrossRef]

40. Ishigami, S.; Natsugoe, S.; Tokuda, K.; Nakajo, A.; Iwashige, H.; Aridome, K.; Hokita, S.; Aikou, T. chain expression in gastric cancer. Cancer Lett. 2001, 168, 87-91. [CrossRef]

41. Yaprak, M.; Erdogan, G.; Aricic, G.; Ozcan, B.; Mesci, A.; Dinckan, A.; Erdogan, O.; Arici, C. Prognostic Value of CD74 and HLA-DR Expressions in Invasive Ductal Breast Cancer. Adv. Breast Cancer Res. 2015, 4, 71-76. [CrossRef]

42. Xu, M.; Qiu, G.; Jiang, Z.; Von Hofe, E.; Humphreys, R.E. Genetic modulation of tumor antigen presentation. Trends Biotechnol. 2000, 18, 167-172. [CrossRef] 